\title{
Öğretmen Adaylarının Sosyal Kaygı Puanlarının Bazı Değişkenlere Göre İncelenmesi
}

\author{
Investigation of the Social Anxiety Score of Pre-service Teachers \\ in Terms of Some Variables
}

\section{Bünyamin ATEŞ*}

Öz: Bu araştırmanın amacı, öğretmen adaylarının sosyal kaygı puanlarını bazı değişkenlere göre (cinsiyet, aile tipi, anne-babanın birliktelik durumu, algılanan anne-baba tutumu, kardeş durumu) incelemektir. Araştırma, tarama modelinde betimsel bir çalışmadır. Araştırma grubunu 2014-2015 öğretim yılında Erzincan Üniversitesi Eğitim Fakültesi'nin farklı lisans programlarında öğrenim gören ve basit seçkisiz olarak belirlenen 382 öğretmen adayı oluşturmuştur. Bu çalışmada veri toplama aracı olarak Sosyal Kaygı Ölçeği ve Kişisel Bilgi Formu kullanılmıştır. Elde edilen verilerin analizinde bağımsız örneklemler için $t$ testi kullanılmıştır. Bu araştırma sonucunda elde edilen bulgulara göre, öğretmen adaylarının sosyal kaygı puanlarının aile tipine, anne-baba birliktelik durumuna, algılanan anne-baba tutumuna ve kardeş durumuna göre anlamlı düzeyde farklılaştığı; cinsiyete göre ise anlamlı düzeyde farklılaşmadığı belirlenmiştir. $\mathrm{Bu}$ bulgular araştırma kapsamında tartışılmış ve önerilerde bulunulmuştur.

Anahtar sözcükler: Sosyal Kaygı, Üniversite, Eğitim Fakültesi, Öğretmen Adayı

\begin{abstract}
The purpose of this study is to investigate social anxiety scores of pre-service teachers in terms of some variables (gender, family type, parents' union status, perceived parental attitudes, having a sibling). Research is a study descriptive survey. Research group was formed simply randomly determined 382 pre-service teachers, studying at various undergraduate programs in the Faculty of Education, Erzincan University in the academic year 2014-2015. As a data collection tool Social Anxiety Scale and Personal Information Form was used in the study. In the analysis of obtained data independent samples ttest was used. According to the findings obtained as a result of this research, social anxiety scores of preservice teachers were found to differed significantly as to family type, parents' union status, perceived parental attitudes and having a sibling, and not to differed significantly as to gender. These findings are discussed in the context of the research and made suggestions.
\end{abstract}

Keywords: Social Anxiety, University, Faculty of Education, Pre-Service Teachers

\section{Giriş}

Sosyal bir varlık olan insanın diğer gelişim alanlarında olduğu gibi sosyal yönden de bir gelişim göstermesi beklenilen bir durumdur. Bireyin sosyal gelişimini başarılı bir şekilde sürdürmesi onun sosyalleşme sürecinin niteliğine (olumlu-olumsuz/sağlıkl1-sağlıksız) bağlıdır. Bu sürece etki eden önemli faktörlerden biri de hiç şüphesiz ki bireyin sahip olduğu etkili kişiler arası ilişkiler ve iletişim becerisidir. Ancak bir toplumdaki tüm bireylerin bu becerilere aynı düzeyde sahip olmaları beklenemez. Bazı bireyler bu becerilere daha fazla sahipken bazı bireylerde ise

\footnotetext{
* Yrd. Doç. Dr., Erzincan Üniversitesi, Eğitim Fakültesi, Psikolojik Danışmanlık ve Rehberlik ABD, Erzincan. bunyaminates81@gmail.com.
} 
bu beceriler daha azdır. Bireylerin etkili kişiler arası ilişki ve iletişim becerilerine sahip olmalarını engelleyen çeşitli faktörler olabilir. Bu faktörlerden birinin de sosyal kaygı olabileceği düşünülmektedir. Çünkü sosyal kaygı yaşayan bireyden etkili bir kişiler arası ilişki ve iletişim becerisi göstermesi beklenemez. Bu bağlamda bireyin kendisini toplumdan ya da kişiler arası iletişim becerisi gerektiren faaliyetlerden geri çekmesi ya da bu tür faaliyetlerde bulunacağ zaman korku ve anksiyete yaşaması olarak bilinen sosyal kaygı kişiler arası bir ilişki ve iletişim problemi olarak değerlendirilebilir (Ateş 2014).

Bireyin kişiler arası ilişkilerini olumsuz yönde etkileyen ve onu yaşamının diğer alanlarında da yetersiz kılan "sosyal kaygı" kavramı, ilk kez 1903'te Janet tarafından kullanılmıştır. Sosyal kayg1 kavramının Diagnostic and Statistical Manual of Mental Disorders DSM-II'da (1968) yer almadığı görülmüş̧ür. Sosyal kaygı kavramı 1966'da Marks ve Gelder tarafından tanımlanmasına karşın ilk kez Ruhsal Bozuklukların Tanısal ve Sayımsal El Kitabı'nın 3. baskısında (DSMIII) yer almıştır (Dilbaz 1997).

Sosyal kaygı kavramı DSM-III'de (1987) kişinin bir ya da daha fazla durumda başkaları tarafindan olası bir incelemeye maruz kalacağı, küçük düşürücü ya da utanç verici şekilde davranacağına dair kalıcı korku durumu olarak tanımlanmıştır. DSM-IV-TR'de $(2001,197)$ ise sosyal kaygı kavramı, "kişinin tanımadık insanlarla karşılaştığı ya da başkalarının gözünün kendi üzerinde olabileceği bir ya da birden fazla toplumsal ya da bir eylemi gerçekleştirdiği durumdan belirgin ve sürekli bir korku duyma hali" olarak tanımlanmıştır.

Yukarıdaki tanımların dışında sosyal kaygı kavramı Hofmann, Anu ve Hinton (2010) tarafından "bireyin diğer insanlar tarafindan olumsuz değerlendirilme korkusu" olarak tanımlanmıştır. Ayrıca Rapee (1995) ise sosyal kaygı kavramını "bireyin başkaları tarafindan değerlendirildiğini ya da incelendiğini düşündüğ̈̈ potansiyel durumlardan korkma veya kaçınma eğilimi" şeklinde tanımlamıştır.

Sosyal kaygı yaşayan birey toplumsal bir durum ve eylem karşısında yaşadığı korkunun aşırı veya anlamsız olduğunu bildiği halde, kişi küçük duruma düşeceği ya da utanç duyacağı bir biçimde davranacağından korkar. Korkulan toplumsal durumlardan kaçınır ya da yoğun anksiyete, sıkıntı ile bunlara katlanır. Bu da kişinin olağan günlük işlerini, mesleki, eğitim ile ilgili işlevselliğini, toplumsal etkinliklerini ve ilişkilerini bozar DSM-IV-TR (2001).

Bireyin ilişkilerinde ve işlevselliğinde bozukluğa neden olan sosyal kaygının birey üzerinde oluşturduğu bazı belirtiler de vardır. Bu belirtiler arasında yüz kızarması, baş dönmesi, nefes almada güçlük, kalp çarpıntısı, mide bulantısı gibi fizyolojik belirtiler; yetersizlik ve kendisine yönelik sosyal durumlarla ilgili işlevsel olmayan olumsuz düşünceler, olumsuz değerlendirme beklentisi gibi bilişsel belirtiler; mahcup olmaktan, aptalca görünmekten veya küçük düşeceğinden korkma gibi duygusal belirtiler ve sosyal ortamlardan kaçınma ya da sessiz kalma, kekeleme, sesin cılız çıkması veya kaybolması, yeni insanlarla tanışmaktan kaçınma, otoriteden çekinme, göz kontağı kurmaktan kaçınma gibi davranışsal belirtiler sayılabilir (Kearney 2005; Kuzucu 2013).

Birey ve bireyin yaşam alanı üzerinde olumsuz bir etkiye sahip olan sosyal kaygı, toplumda oldukça yaygın görülen bir bozukluktur (Binbay \& Koyuncu 2012). Sosyal kaygının başlangıç yaş1 13-24 arasında değişmekle birlikte (Dilbaz 1997; İzgiç et al. 2000; Caballo et al. 2008; Koyuncu et al. 2012) genel olarak toplumdaki yaygınlık oranı \%3 ile \%13 arasında değişmektedir. Sosyal kaygı Amerika Birleşik Devletleri'nde psikolojik bozukluklar siralamasında majör depresif bozukluk ve alkol bağımlılı̆̆ından sonra üçüncü sırada yer alarak en çok görülen üç psikolojik bozukluk içindedir. (Kessler et al. 1994; Dilbaz 1997; Talepasand \& Nokani 2010). Sadece üniversite gençliği göz önüne alındığında ise sosyal kaygının yaygınlık oranının yaklaşık 
olarak \%7 ile \%21 arasında değiştiği görülmektedir (İzgiç et al. 2000; Tillfors \& Furmark 2007; Yeniçıktı 2010; Gültekin \& Dereboy 2011; Iancu \& Ram 2011; Baptista et al. 2012).

Gerek başlangıç yaşı gerekse üniversite gençliğindeki yaygınlık oranı açısından değerlendirildiğinde üniversite öğrencileri arasında sosyal kaygının ciddi bir psikolojik sorun olduğu görülmektedir. Türkiye'deki üniversite gençliğinin önemli bir kısmını eğitim fakültelerinde öğrenim gören öğretmen adayları oluşturduğu düşünüldüğünde bu genellemeye öğretmen adayları da dahil edilebilir.

Üniversite öğrencilerinde bulunması gereken en önemli özelliklerden birisi de etkili iletişim ve kişiler arası ilişkiler becerisidir. Her bir üniversite öğrencisinin bu becerilere belli düzeyde sahip olması beklenmekle birlikte öğretmen adaylarının bu becerilere daha üst düzeyde sahip olması beklenir. Çünkü öğretmen adaylarının gelecekte icra edecekleri öğretmenlik mesleği toplumla iç içe sürdürülen bir meslektir. Öğretmenlik mesleğinde toplumu oluşturan bireyler ile doğrudan bir iletişim kurma gerekliliği vardır. Doğal olarak da bu mesleği yürütecek olan her bir öğretmen adayının etkili iletişim ve kişiler arası ilişkiler becerisine sahip olması yerinde bir beklentidir. Ancak öğretmen adaylarının bu becerileri sergilemelerine engel olabilecek bazı faktörler olabilir. Bu faktörlerden birinin de sosyal kaygı olabileceği düşünülmektedir.

$\mathrm{Bu}$ bağlamda yapılan araştırma, öğretmen adaylarının kişisel, sosyal ve eğitim hayatını doğrudan etkileyebilen sosyal kaygı değişkeni ile bağlantılı olabilecek değişkenlerin belirlenmesi bakımından alanda bir farkındalık oluşturabilmesi; koruyucu ve iyileştirici ruh sağlığ açısından, profesyonel çalışmalarda alanın uzmanlarına yol gösterici olabilmesi ve alana katkı sunabilmesi bakımından önemli görülmektedir.

Bu noktalardan hareketle bu araştırmanın amacı, öğretmen adaylarının sosyal kaygı puanlarını bazı değişkenlere göre (cinsiyet, aile tipi, anne-babanın birliktelik durumu, algılanan anne-baba tutumu, kardeş durumu) incelemektir. Algılanan anne-baba tutumlarının belirlenmesinde öğretmen adaylarının görüşleri esas alınmıştır.

\section{Yöntem}

\subsection{Araştırma Modeli}

Araştırma, öğretmen adaylarının sosyal kaygı puanlarını bazı değişkenlere göre incelenmeye yönelik tarama modelinde betimsel bir çalışmadır.

\subsection{Araştırma Grubu}

Bu çalışmanın araştırma grubunu 2014-2015 öğretim yılında Erzincan Üniversitesi Eğitim Fakültesi'nin farklı lisans programlarında öğrenim gören ve liste yöntemine dayalı, seçkisiz olarak belirlenen, 204'ü $(\% 53,4)$ kız ve 178 'i $(\% 46,6)$ erkek olmak üzere toplam 382 öğretmen adayı oluşturmuştur.

\subsection{Veri Toplama Araçları}

\subsubsection{Sosyal Kaygı (Anksiyete) Ölçeği (SKÖ)}

Ölçek Özbay-Palancı (2001) tarafından üniversite öğrencilerinin yaşadığı "sosyal kaygl" içerikli sorunları belirlemek amacıyla geliştirilmiştir. Üniversite öğrenci popülasyonuna yönelik kullanışl1lığa sahip olacak şekilde geliştirilen ölçek, üniversite öğrencilerinin sosyal durumlara uygun becerilerini ve bu durumlarda oluşabilecek kaygılarını ölçebilecek yapıda hazırlanmıştır. Test kriter ve yapı geçerliliğine tabi tutulmuştur. Kriter geçerliliği için SCL-90 (Belirti Tarama Listesi) ölçeğinin ilgili dört alt ölçeği ve MMPI (Minnesota Çok Yönlü Kişilik Envanteri) sosyal içedönüklük (Si) alt testi kullanılmıştır. Yap1 geçerliliğine yönelik faktör analizi sonu- 
cunda 30 maddelik üç faktörlü bir test yapısı oluşmuştur. Faktör analizi SPSS 10.0 ile gerçekleştirilmiştir. Yapılan faktör analizinde faktörlenebilirlik değişik yöntemlerle incelenmiştir. İlk olarak bütün maddeler arasındaki korelasyon matriksleri incelenmiş ve uygunluk aranmıştır. Örneklem uygunluğu ve Sphericity testleri gerçekleştirilmiştir. KMO örneklem uygunluk katsayısı .90, Barlett Sphericity 3644.58 ile $\mathrm{p}<.001$ düzeyinde anlamlı bulunmuştur. Yapılan ilk faktör analizinde döngüsel metot kullanılarak faktör çözümlemesinin birden büyük öz değerleri grafikleme yöntemiyle (scree test) maksimum manidar faktör sayısı incelenmiştir. Uygunluk gösteren ve açıklanabilir faktör sayısının üç olduğu belirlenmiştir. Varimax rotasyon faktör çözümlemesinin sonuçlarıyla elde edilen bu üç faktör (1) sosyal kaçınma, (2) kritize edilme kaygısı ve (3) bireysel değersizlik duygusu olarak adlandırılmıştır. Üç faktörün açıkladığı toplam varyans $\% 32.9$ 'dur.

Sosyal Kaçma: Bu faktör sosyal ilişkilerden kaçınma, iletişim kurma isteksizliği, sosyal etkileşim kaygısı, konuşma güçlüğü, kalabalığa karışma, otoriter kaygısı yaşama, görünme ve gözleme sorunları gibi sosyal kaygı bağlamında ele alınabilecek çeşitli durum ve semptomları içermektedir. Toplam varyansın 22.3'ünü açılayan faktör 12 maddeden oluşmuştur.

Kritize Edilme Kaygısı: Kendini kontrol etme çabalarının fazlalığı, hatalı davranmaktan korkma, küçük düşme, reddedilme kaygısı gibi kaygıları içeren bu faktör toplam varyansın 6.2'sini açıklamaktadır.

Bireysel Değersizlik Duygusu: Kendini değersiz hissetme, kendinden memnun olmama, başkasından yardım alamama, başarısızlık kimliği, eleştiri ve kişisel özelliklerini kabul etmeme gibi içerikleri yansıtan faktör varyansın 4.4'ünü açıklamaktadır.

Testin kriter geçerliği için kullanılan MMPI Si alt testi ile $\mathrm{r}=.43, \mathrm{p}<.001$, SCL alt testlerinden kişiler arası ilişkilerde duyarlılık alt testi ile, $\mathrm{r}=.51, \mathrm{p}<.001$, kaygı testi ile, $\mathrm{r}=.25$, $\mathrm{p}<.01$, fobik anksiyete alt testi ile $\mathrm{r}=.36, \mathrm{p}<.001$, depresyon alt testi ile $\mathrm{r}=.40, \mathrm{p}<.001$ düzeyinde kuramsal açıklamaya uygun pozitif lineer ilişkilerin bulunduğu görülmüştür. Güvenirlik hesaplamaları ile dağılıma ilişkin uygunluğun elverişliliği analiz edilmiştir. Yapılan varyans analizi sonucunda $\mathrm{F}=68.58, \mathrm{P}<.001$ düzeyinde sonuç anlamlı bulunmuştur. Güvenirlik hesaplamaları için test içi tutarlılık yöntemi ile hesaplanan Cronbah Alfa değeri .89'dur. Test likert tipi 0-4 aralığında beşli derecelendirmeye sahiptir. Alınan puanların yükselmesi sosyal kayg1 (sosyal fobi) düzeyinin yükseldiğini göstermektedir (Özbay \& Palancı 2001).

Palanc1 (2004) tarafından toplanan 650 öğrenciye ait sosyal kaygı (anksiyete) ölçeği verileri üzerinde ölçeğin güvenirlik puanı, test iç tutarlılık yöntemiyle yeniden hesaplanmış. Ölçek geliştirildikten yaklaşık üç yıl sonra başka bir örneklem üzerinde gerçekleştirilen işlem sonucunda Cronbah Alfa değeri .88 olarak hesaplanmıştır.

\subsubsection{Kişisel Bilgi Formu}

Kişisel bilgi formu, araştırma grubunu oluşturan öğretmen adaylarının kişisel bilgilerini (cinsiyet, aile tipi, anne-babanın birliktelik durumu, algılanan anne-baba tutumu, kardeş durumu) elde etmek amacıyla bu araştırma kapsamında geliştirilmiştir.

\subsection{Verilerin Toplanması}

Araştırmada kullanılan veri toplama araçları öğretmen adaylarına araştırmacı tarafından gruplar halinde uygulanmıştır. Veri toplama araçları gruplara uygulanmadan önce araştırmanın amacı hakkında gruplara bilgi verilmiştir. Verilerin toplanmasında öğretmen adaylarının gönüllülüğü esas alınmıştır. Her bir grupta uygulamalar yaklaşık olarak 30 dakika sürmüştür. 


\subsection{Verilerin Analizi}

Araştırmada ilk önce elde edilen verilerin parametrik istatistikler için uygun olup olmadıkları normallik dağılımına (çarpıklık, basıklık, ortalama, ortanca, mod) ve grupların varyanslarının eşitliğine (Levene F testi) bakılarak incelenmiş. Elde edilen verilerin normal dağılım gösterdiği, grupların varyanslarının eşit olduğu ve bu bakımdan da parametrik istatistikler için uygun olduğu belirlenmiş. Daha sonra sosyal kaygı ile ilgili ele alınan bağımsız değişkenlerin düzeylerine göre oluşturulan grupların bağımlı değişken puanlarının anlamlı olarak farklılaşıp farklılaşmadığını belirlemek amacıyla ilişkisiz (bağımsız) örneklemler için $t$ testi kullanılmıştır. Veri analizleri SPSS programları aracılığı ile bilgisayar ortamında yapılmıştır. Gruplar arasındaki farkın anlamlı olup olmadığı yorumlanırken p değeri .05 olarak kabul edilmiştir (Büyüköztürk 2011; Can 2013).

\section{Bulgular}

Öğretmen adaylarının sosyal kaygı puan ortalamalarının cinsiyete, aile tipine, anne-babanın birliktelik durumuna, algılanan anne-baba tutumuna, kardeş durumuna göre farklılaşıp farklılaşmadığını belirlemede bağımsız örneklemler için $t$ testi kullanılmış ve sonuçlar Tablo 1'de sunulmuştur.

Tablo 1. Sosyal Kaygı Puan Ortalamalarının Cinsiyete, Aile Tipine, Anne-Babanın Birliktelik Durumuna, Algılanan Anne-Baba Tutumuna, Kardeş Durumuna Göre t-Testi Sonuçları

\begin{tabular}{|c|c|c|c|c|c|c|c|}
\hline & & $\mathbf{N}$ & $\bar{X}$ & $\mathbf{S}$ & Sd & $\mathbf{t}$ & $\mathbf{p}$ \\
\hline \multirow{2}{*}{ Cinsiyet } & $\mathbf{K} \mathbf{z} \mathbf{z}$ & 204 & 32.95 & 10.03 & 380 & -1.66 & .098 \\
\hline & Erkek & 178 & 34.70 & 10.62 & & & \\
\hline \multirow{2}{*}{ Aile Tipi } & Çekirdek & 319 & 32.78 & 9.84 & 380 & -4.30 & .000 \\
\hline & Geniş & 63 & 38.77 & 11.35 & & & \\
\hline \multirow{2}{*}{$\begin{array}{l}\text { Anne-Baba } \\
\text { Birlikteliği }\end{array}$} & Birlikte & 350 & 33.33 & 10.27 & 380 & 2.76 & .006 \\
\hline & Ayrı & 32 & 38.56 & 9.93 & & & \\
\hline \multirow{2}{*}{$\begin{array}{l}\text { Algilanan } \\
\text { Anne } \\
\text { Tutumu }\end{array}$} & Demokratik & 265 & 31.88 & 9.64 & 380 & 5.56 & .000 \\
\hline & $\begin{array}{l}\text { Demokratik } \\
\text { Değil }\end{array}$ & 117 & 38.03 & 10.61 & & & \\
\hline \multirow{2}{*}{$\begin{array}{l}\text { Algılanan } \\
\text { Baba Tutumu }\end{array}$} & Demokratik & 258 & 32.66 & 9.84 & 380 & 3.04 & .003 \\
\hline & $\begin{array}{l}\text { Demokratik } \\
\text { Değil }\end{array}$ & 124 & 36.06 & 10.98 & & & \\
\hline \multirow{2}{*}{$\begin{array}{l}\text { Kardeş } \\
\text { Durumu }\end{array}$} & Kardeşi var & 314 & 32.91 & 10.00 & 380 & 3.51 & .000 \\
\hline & Kardeşi yok & 68 & 37.70 & 10.99 & & & \\
\hline
\end{tabular}

Öğretmen adaylarının sosyal kaygı puan ortalamalarının cinsiyete göre anlamlı düzeyde bir farklılaşma gösterip göstermediğini belirlemek için yapılan bağımsız örneklemler $t$ testi sonucunda kızların sosyal kayg1 puan ortalaması ile $(\bar{X}=32.95)$ erkeklerin sosyal kayg1 puan ortalaması ( $\bar{X}=34.70$ ) arasında anlamlı düzeyde bir fark görülmemiştir [ $\mathrm{t}(380)=-1.66, \mathrm{p}>.05]$.

Elde edilen sonuçlara göre çekirdek aile tipine sahip öğretmen adaylarının sosyal kaygı puan ortalaması ile $(\bar{X}=32.78)$ geniş aile tipine sahip öğretmen adaylarının sosyal kaygı puan ortalaması ( $\bar{X}=38.77)$ arasında çekirdek aile tipine sahip öğretmen adayları lehinde anlamlı düzeyde bir fark görülmüştür. [t(380)=-4.30, p<.05]. Etki büyüklüğünü belirlemek için hesaplanan eta kare değeri $(\eta 2=.046$ )'dir. Bu durumda sosyal kayg1 puanlarında gözlenen varyansın yaklaşık $\% 5$ 'nin aile tipine bağlı olduğu söylenebilir. 
Yukarıdaki bulgulara göre anne-babası birlikte olan öğretmen adaylarının sosyal kaygı puan ortalaması ile ( $\bar{X}=33.33)$ anne-babası ayrı (ölüm, boşanma vb.) olan öğretmen adaylarının sosyal kaygı puan ortalaması ( $\bar{X}=38.56)$ arasında anne-babası birlikte olan öğretmen adayları lehinde anlamlı düzeyde bir fark görülmüştür $[\mathrm{t}(380)=2.76, \mathrm{p}<.05]$. Etki büyüklüğünü belirlemek için hesaplanan eta kare değeri $(\eta 2=.020)$ 'dir. Bu durumda sosyal kaygı puanlarında gözlenen varyansın yaklaşı \%2'sinin anne-babanın birliktelik durumuna bağlı olduğu söylenebilir.

Tablo 1 incelendiğinde anne tutumunu demokratik olarak algılayan öğretmen adaylarının sosyal kayg1 puan ortalaması ile $(\bar{X}=31.88)$ anne tutumunu demokratik olarak algilamayan (otoriter, koruyucu, ilgisiz) öğretmen adaylarının sosyal kaygı puan ortalaması $(\bar{X}=38.03)$ arasında anne tutumunu demokratik olarak algılayan öğretmen adayları lehinde anlamlı düzeyde bir fark görülmüştür. $[\mathrm{t}(380)=5,56, \mathrm{p}<.05]$. Etki büyüklüğünü belirlemek için hesaplanan eta kare değeri $(\eta 2=.075)$ 'dir. Bu durumda sosyal kaygı puanlarında gözlenen varyansın yaklaşık $\% 8$ 'nin algılanan anne tutumuna bağlı olduğu söylenebilir.

Yukarıdaki bulgulara göre baba tutumunu demokratik olarak algılayan öğretmen adaylarının sosyal kayg1 puan ortalamas1 ile $(\bar{X}=32.66)$ baba tutumunu demokratik olarak algilamayan (otoriter, koruyucu, ilgisiz) öğretmen adaylarının sosyal kaygı puan ortalaması ( $\bar{X}=36.06)$ arasinda baba tutumunu demokratik olarak algılayan öğretmen adayları lehinde anlamlı düzeyde bir fark görülmüştür. $[\mathrm{t}(380)=3.04, \mathrm{p}<.05]$. Etki büyüklüğünü belirlemek için hesaplanan eta kare değeri $(\eta 2=.024)$ 'dir. Bu durumda sosyal kaygı puanlarında gözlenen varyansın yaklaşık $\% 2$ 'sinin algılanan baba tutumuna bağl1 olduğu söylenebilir.

Öğretmen adaylarının sosyal kaygı puan ortalamalarının kardeş durumuna göre anlamlı düzeyde bir farklılaşma gösterip göstermediğini belirlemek için yapılan bağımsız örneklemler $t$ testi sonucunda kardeşi olan öğretmen adaylarının sosyal kaygı puan ortalaması ile $(\bar{X}=32.91)$ kardeşi olmayan öğretmen adaylarının sosyal kaygı puan ortalaması $(\bar{X}=37.70)$ arasında kardeşi olan öğretmen adayları lehinde anlamlı düzeyde bir fark görülmüştür. [t(380)=3.51, p<.05]. Etki büyüklüğünü belirlemek için hesaplanan eta kare değeri $(\eta 2=.031)$ 'dir. Bu durumda sosyal kaygı puanlarında gözlenen varyansın yaklaşık \%3'ünün kardeş durumuna bağlı olduğu söylenebilir.

\section{Sonuç, Tartışma ve Öneriler}

Öğretmen adaylarının sosyal kaygı puanlarının bazı değişkenlere göre (cinsiyet, aile tipi, annebabanın birliktelik durumu, algılanan anne-baba tutumu, kardeş durumu) incelendiği bu araştırma sonucunda, öğretmen adaylarının sosyal kaygı puan ortalamalarının cinsiyete göre anlamlı düzeyde farklılaşmadığı görülmüştür. Bu durumda öğretmen adaylarının sosyal kaygı puanları üzerinde cinsiyetin anlamlı düzeyde bir etkisinin olmadığı söylenebilir. Bu bağlamda yapılan alan yazın taramasında sosyal kaygının kızlara oranla erkeklerde daha çok görüldügünü tespit eden araştırma sonuçları olduğu gibi (Dilbaz \& Güz 2002; Noyan \& Berk 2007) erkeklere oranla kızlarda daha çok görüldüğünü tespit eden (Schneier et al. 1992; Kaya et al. 1997; Weinstock 1999; Caballo et al. 2008; Talepasand \& Nokani 2010; Gültekin \& Dereboy 2011; Memik et al. 2011) ve cinsiyet açısından bir farklılaşma olmadığını tespit eden (Eren-Gümüş 1997; Ümmet 2007; Aune \& Stiles 2009; Göktürk 2011) araştırma sonuçlarına rastlanmıştır. Bu bağlamda araştırma sonuçlarındaki farklılığın araştırma gruplarının özelliklerinden kaynaklandığı düşünülmekle birlikte sosyal kaygının değişen toplum şartlarına bağlı olarak gerek kızlar için gerekse erkekler için meslek, iş, aile, eğitim ve nihai olarak sosyal yaşantıyı olumsuz yönde etkileyen bir psikolojik sorun olduğu söylenebilir. Araştırma sonucunda elde edilen bu bulgu değişen kültürel ve toplum şartlarına bağlı olarak kızlara ve erkeklere atfedilen sosyal statü, rol 
ve sorumlulukların benzer olmasından dolayı sosyal kaygıya benzer oranda maruz kalmaları şeklinde yorumlanabilir. Bu durumun öğretmen adayları için de geçerli olduğu düşünülmektedir.

Araştırmada elde edilen başka bir bulguya göre, çekirdek aile tipine sahip öğretmen adaylarının sosyal kaygı puan ortalaması ile geniş aile tipine sahip öğretmen adaylarının sosyal kaygı puan ortalaması arasında çekirdek aile tipine sahip öğretmen adayları lehinde anlamlı düzeyde bir fark görülmüştür. Yani çekirdek aileye mensup öğretmen adaylarının sosyal kayg1 puanlarının daha düşük olduğu tespit edilmiştir. Bu durumda öğretmen adaylarının sosyal kayg1 puanları üzerinde aile tipinin anlamlı düzeyde bir etkisinin olduğu söylenebilir. Bu konuda yapılan alan yazın taramasında Erkan (2002) tarafından yapılan araştırmada öğrencilerin sosyal kayg1 düzeylerinin geniş ya da çekirdek aile tipine göre farklılaşmadığı ve aile tipinin sosyal kayg1 için bir risk faktörü oluşturmadığ 1 belirlenmiştir. Araştırma sonucundaki farklılığın araştırma gruplarının özelliklerinden kaynaklanabileceği düşünülmekle birlikte yapılan bu araştırma sonucundan hareketle çekirdek aile yapısının bireylerin sosyal gelişimi açısından destekleyici unsurlardan biri olduğu ve dolayısıyla sosyal içerikli bir sorun olan sosyal kaygıya karşıda koruyucu bir fonksiyona sahip olduğu söylenebilir. Bunda çekirdek ailede aile bireylerinin düşünce ve duygularını paylaşırken geniş aileye göre daha az sosyal baskı hissetmelerinin etkili olabileceği düşünülmektedir.

Yapılan araştırma sonucunda anne-babası birlikte olan öğretmen adaylarının sosyal kaygı puan ortalaması ile anne-babası ayrı (ölüm, boşanma vb.) olan öğretmen adaylarının sosyal kayg1 puan ortalaması arasında anne-babası birlikte olan öğretmen adayları lehinde anlamlı düzeyde bir fark görülmüştür. Anne-babası birlikte olan öğretmen adaylarının sosyal kaygı puanlarının daha düşük olduğu belirlenmiştir. Bu durumda öğretmen adaylarının sosyal kaygı puanları üzerinde anne-babanın birliktelik durumunun anlamlı düzeyde bir etkisinin olduğu söylenebilir. Yapılan alan yazın taramasında Kalkan (2008) tarafından yapılan araştırmada ergenlerin sosyal kaygı düzeylerinin anne-babanın birliktelik durumuna göre değişmediği görülmüştür. Araştırma sonuçlarındaki bu farklılığa rağmen anne-babanın ayrı olması ya da parçalanmış ailede yetişmenin sosyal kaygı açısından bir risk oluşturabileceği düşünülmektedir. Çünkü birey ilk sosyal etkileşimini (sosyalleşme) ailesi ile özellikle de anne babası ile kurar. Bu bakımdan bireyin sağlıklı sosyalleşmesi ve etkili kişiler arası iletişim becerilerine sahip olmasında anne babanın önemli bir yeri vardır. Bireyin sosyal gelişim sürecinde anne-babadan almış olduğu sosyal destek onun sağlıklı olarak sosyalleşmesine katkı sunarken kişiler arası etkileşim ve iletişim problemi olarak nitelendirilebilecek sosyal kaygıya karşı koruyucu bir fonksiyonu da yerine getirmiş olur. Bireylerin sağlıklı kişiler arası iletişim becerilerine sahip olmaları ve dolayısıyla sosyal kaygı problemi yaşamamaları için sosyal açıdan sağlıklı aile ortamlarında yetişmiş olmaları önem arz etmektedir. Sosyal açıdan sağlıklı aile ortamının en önemli göstergelerinden birisinin de aile bütünlügü olduğu ve bu bütünlüğün de bireyleri sosyal kaygıya karşı koruduğu düşünülmektedir. Bu araştırmadan elde edilen bulgulardan hareketle anne-babanın birlikteliğinin başka bir ifade ile ailenin parçalanmamış olmasının bireylerin sosyal kaygı probleminden uzak, sağlıklı bir sosyal gelişim süreci yaşamalarına ve etkili iletişim becerilerine sahip olmalarına katkı sunduğu söylenebilir. Bu noktada anne-baba birlikteliği ruh sağlığı açısından önemli görülmektedir.

$\mathrm{Bu}$ araştırma sonucunda elde edilen bir başka bulguya göre, anne-baba tutumunu demokratik olarak algılayan öğretmen adaylarının sosyal kaygı puan ortalaması ile anne-baba tutumunu demokratik olarak algılamayan (otoriter, koruyucu, ilgisiz) öğretmen adaylarının sosyal kaygı puan ortalaması arasında anne-baba tutumunu demokratik olarak algılayan öğretmen adayları lehinde anlamlı düzeyde bir fark görülmüştür. Anne-baba tutumunu demokratik olarak algılayan öğretmen adaylarının sosyal kaygı puan ortalamasının daha düşük olduğu belirlenmiştir. Bu 
durumda öğretmen adaylarının sosyal kaygı puanları üzerinde algılanan anne-baba tutumlarının anlamlı düzeyde bir etkisinin olduğu söylenebilir. Bu bulgu (Erkan 2002; Türe 2009; Festa \& Ginsburg 2011; Kaya et al. 2012) tarafından yapılan çalışmalarla tutarlılık göstermektedir. Bu çalışmalarda da demokratik anne-baba tutumlarının hakim olduğu aile ortamlarında yetişen bireylerin sosyal kaygı düzeylerinin daha düşük düzeyde olduğu tespit edilmiştir. Demokratik anne-baba tutumlarının egemen olduğu aile ortamları bireylerin duygu ve düşüncelerini açıkça ifade etmesine imkan veren, onları destekleyen açı sistemlerdir. Bu tür aile ortamlarında bireysel farklılıklara saygı duyulur, roller tutarlı, kurallar ve beklentiler açıktır ve doğal olarak da bu tür aile ortamlarında bireyler herhangi bir sosyal baskı hissetmeden aile üyelerinden almış oldukları sosyal destekle kendi duygu ve düşüncelerini çekinmeden, kayg1 yaşamadan rahatça ifade edebilirler. Demokratik bir aile ortamında kendisini rahat bir şekilde ifade edebilen bireylerin aile dışındaki sosyal yaşantılarında da sosyal bir baskı hissetmeden kendi istek ve beklentilerini açıkça ifade edebilecekleri söylenebilir. $\mathrm{Bu}$ araştırma bulgularından hareketle demokratik aile ortamlarının bireyleri sosyal kaygıya karşı koruyan bir işlevi olduğu söylenebilir. Bu bakımdan da anne-babaların mevcut tutumlarını gözden geçirerek daha demokratik tutum takınmaları konusunda çaba göstermelerinin koruyucu ruh sağlığı açısından önemli olduğu düşünülmektedir. Yapılan araştırma sonucunda kardeşi olan öğretmen adaylarının sosyal kayg1 puan ortalaması ile kardeşi olmayan öğretmen adaylarının sosyal kaygı puan ortalaması arasında kardeşi olan öğretmen adayları lehinde anlamlı düzeyde bir fark görülmüştür. Kardeşi olan öğretmen adaylarının sosyal kaygı puanlarının daha düşük olduğu belirlenmiştir. Bu durumda öğretmen adaylarının sosyal kaygı puanları üzerinde kardeş durumunun anlamlı düzeyde bir etkisinin olduğu söylenebilir. Bu bulgu ile ilgili yapılan alan yazın taramasında sosyal kaygının farkl1 değişkenlere göre incelendiği görülmüş (Aybay 2009; Thomasson \& Psouni 2010; Hampel et al. 2011; Kurtyılmaz 2011; Baltacı \& Hamarta 2013), ancak kardeşin olup olmamas1 durumuna göre sosyal kaygı puanlarının incelendiği bir araştırmaya rastlanmamıştır. Toplumun küçük bir modeli olan aile, sosyal iletişim becerilerinin kazanıldığı ilk ortamdır. Bireylerin etkili iletişim ve sosyal becerileri kazanmalarında anne babanın yanı sıra kardeşler arası ilişkilerin de önemli olduğu ve bu noktada kardeş varlığının sosyal açıdan destekleyici bir unsur, sosyal kaygıya karşı koruyucu bir faktör olabileceği düşünülmektedir. Bu bağlamda ruhsal açıdan kardeş yokluğunun oluşturabileceği risk durumlarına karşı kaliteli aile içi iletişim ve arkadaş ilişkilerinin koruyucu ruh sağlığ 1 açısından önemli olduğu düşünülmektedir. Bu araştırmadan elde edilen sonuçlar çerçevesinde aşağıdaki önerilerde bulunulmuştur.

- Araştırma sonuçlarından hareketle çekirdek aile yapısının, anne-baba birlikteliğinin, demokratik anne-baba tutumlarının ve kardeş varlığının sosyal kaygıya karşı koruyucu birer unsur olduğu söylenebilir. Bu bağlamda bu unsurların sosyal kaygıya karşı koruyucu katkısını göz önünde bulundurarak çeşitli çalışmalara (eğitim çalışmaları, seminerler vb.) yer verilebilir.

- Bu çalışmada anne-baba tutumları araştırma grubunun algılarına göre değerlendirilmiştir. Benzer bir çalışmada anne-baba tutumlarının belirlenmesine yönelik bir ölçme aracı kullanılabilir.

- Benzer bir çalışma farklı fakülteler veya bölümlerde aynı ya da farklı değişkenlerle de yürütülebilir.

- Bu çalışma Erzincan Üniversitesi, Eğitim Fakültesi ile sınırlıdır. Bu bağlamda elde edilen sonuçlar sadece benzer gruplara genellenebilir. 


\section{KAYNAKÇA}

American Psychiatric Association. (1968). Diagnostic and Statistical Manual of Mental Disorders (DSMII). Washington, DC 1968.

American Psychiatric Association. (1987). Diagnosic and Statistical Manual of Mental Disorders (DSMIII-R). Washington, DC 1987.

Amerikan Psikiyatri Birliği. $\left(2001^{4}\right)$. Psikiyatride Hastalıkların Tanımlanması ve Sintflandırlması Elkitabı (DSM-IV-TR). Çev. E. Köroğlu. Washington DC, Ankara 2001.

Ateş B. (2014). Üniversite Öğrencilerinin Sosyal Fobi ile Başa Çıkmalarında Çözüm Odaklı Grupla Psikolojik Danışmanın Etkisinin Incelenmesi. Yayımlanmamış Doktora Tezi. Atatürk Üniversitesi, Eğitim Bilimler Enstitüsü, Erzurum 2014.

Auna T. \& Stiles T. C. (2009). "The Effects of Depression and Stressful Life Events on the Development and Maintenance of Syndromal Social Anxiety: Sex and Age Differences". Journal of Clinical Child \& Adolescent Psychology 38/4 (2009) 501-512.

Aybay L. E. (2009). 8-12 Yaş Grubu Kekeme Çocukların Kaygl, Sosyal Fobi ve Zeka Yönünden Tetkiki. Yayımlanmamış Yüksek Lisans Tezi. Maltepe Üniversitesi, Sosyal Bilimler Enstitüsü, İstanbul 2009.

Baltacı Ö. \& Hamarta E. (2013). "Üniversite Öğrencilerinin Sosyal Kayg1, Sosyal Destek ve Problem Çözme Yaklaşımları Arasındaki İlişkinin İncelenmesi”. Eğitim ve Bilim 38/167 (2013) 226-240.

Baptista C. A., Loureiro S. R., Zuardi A. W., Magalhaes P. V., Kapczinski F., Filho A. S. et al. (2012). "Social Phobia in Brazilian University Students: Prevalence, Under-Recognition and Academic Impairment in Women". Journal of Affective Disorders 136/3 (2012) 857-861.

Binbay Z. \& Koyuncu A. (2012). "Sosyal Anksiyete Bozukluğu ve Duygudurum Bozuklukları Birlikteliği”. Psikiyatride Güncel Yaklaşımlar 4/1 (2012) 1-13.

Büyüköztürk Ş. (2011). Sosyal Bilimler İ̧̧in Veri Analizi El Kitabı. Ankara 2011.

Caballo V. E., Salazar I. C., Irurtia M. J. Arias B. \& Hofmann S. G. (2008). "Social Anxiety in 18 Nations: Sex and Age Differences". Behavioral Psychology 16/2 (2008) 163-187.

Can A. (2013). SPSS ile Bilimsel Araştırma Sürecinde Nicel Veri Analizi. Ankara 2013.

Dilbaz N. (1997). "Sosyal Fobi”. Psikiyatri Dünyası 1 (1997) 18-24.

Dilbaz N. \& Güz H. (2002). "Sosyal Kaygı Bozukluğunda Cinsiyet Farklılıkları". Nöropsikiyatri Arşivi 39/3-4 (2002) 79-86.

Eren-Gümüş A. (1997). Üniversite Öğrencilerinin Sosyal Kaygı Düzeylerinin Çeşitli Değişkenlere Göre Incelenmesi. Yayımlanmamış Yüksek Lisans Tezi. Gazi Üniversitesi, Sosyal Bilimler Enstitüsü, Ankara 1997.

Erkan Z. (2002). Ergenlerin Sosyal Kaygı Düzeyleri, Ana-Baba Tutumları ve Ailede Görülen Risk Faktörleri Üzerine Bir Çalışma. Yayımlanmamış Doktora Tezi. Çukurova Üniversitesi, Sosyal Bilimler Enstitüsü, Adana 2002.

Festa C. C. \& Ginsburg G. S. (2011). "Parental and Peer Predictors of Social Anxiety in Youth". Child Psychiatry \& Human Development 42 (2011) 291-306.

Göktürk G. Y. (2011). Ergenlerin Sosyal Kaygı Düzeylerinin Özgüven ve Bazı Kişisel Demografik Özelliklere Göre İncelenmesi. Yayımlanmamış Yüksek Lisans Tezi. Abant İzzet Baysal Üniversitesi Eğitim Bilimler Enstitüsü, Bolu 2011.

Gültekin B. K. \& Dereboy İ. F. (2011). "Üniversite Öğrencilerinde Sosyal Fobinin Yaygınlığı ve Sosyal Fobinin Yaşam Kalitesi, Akademik Başarı ve Kimlik Oluşumu Üzerine Etkileri”. Türk Psikiyatri Dergisi 22/3 (2011) 150-158.

Hampel S., Weis S., Hiller W. \& Witthöft M. (2011). "The Relations Between Social Anxiety and Social Intelligence: A Latent Variable Analysis". Journal of Anxiety Disorders 25/4 (2011) 545553.

Hofmann S. G., Anu A. M. A. \& Hinton D. E. (2010). "Cultural Aspects in Social Anxiety and Social Anxiety Disorder". Depression and Anxiety 27 (2010) 1117-1127.

Iancu L. \& Ram E. (2011). "Shyness and Social Phobia in Israeli Jewish Versus Arab Students". European Psychiatry 26/1 (2011) 459-466. 
İzgiç F., Akyüz G., Doğan O. \& Kuğu N. (2000). "Üniversite Öğrencilerinde Sosyal Fobi Yaygınlığı". Anadolu Psikiyatri Dergisi 1/4 (2000) 207-214.

Kalkan N. (2008). Ergenlerde Bilişsel Yapılar ve Sosyal Kaygı Arasındaki İlişkinin Bilişsel Davranış̧̧ı Yaklaşım Açısından Yorumlanması. Yayımlanmamış Yüksek Lisans Tezi. Marmara Üniversitesi, Eğitim Bilimleri Enstitüsü, İstanbul 2008.

Kaya A., Bozaslan H. \& Genç G. (2012). "Üniversite Öğrencilerinin Anne-Baba Tutumlarının Problem Çözme Becerilerine, Sosyal Kaygı Düzeylerine ve Akademik Başarılarına Etkisi”. Dicle Üniversitesi Ziya Gökalp Eğitim Fakültesi Dergisi 18 (2012) 208-225.

Kaya N., Çilli A. S., Aşkın R., Herken H., Özkan İ. \& Kucur R. (1997). "Orta ve Yükseköğrenim Öğrencilerinde Sosyal Fobik Belirti Yaygınlı̆̆ı”. Genel Tip Dergisi 7/3 (1997) 133-137.

Kearney C. A. (2005). Social Anxiety and Social Phobia in Youth. USA 2015.

Kessler R. C., Mc Gonagle K. A., Zhao S., Nelson C. B., Hughes M., Eshleman S. et al. (1994). "Lifetime and 12 Month Prevalence of DSM-III-R Psychiatric Disorders in the United States". Archives of General Psychiatry 51 (1994) 8-19.

Koyuncu A., Binbay Z., Özyıldırım İ. \& Ertekin E. (2012). "Sosyal Anksiyete Bozukluğunda Başlangıç Yaşının Klinik Gidiş Üzerine Etkisi”. Klinik Psikiyatri 15 (2012) 111-120.

Kurtyılmaz Y. (2011). Üniversite Öğrencilerinin Ilişsisel Saldırganlık ile Benlik Saygısl, Sosyal Bağlllık ve Sosyal Kaygı Düzeyleri Arasındaki İlişkiler. Yayımlanmamış Doktora Tezi. Anadolu Üniversitesi, Eğitim Bilimleri Enstitüsü, Eskişehir 2011.

Kuzucu Y. $\left(2013^{3}\right)$. Küçükler İçin Büyüklere Çocuk ve Ergen Ruh Sağllğ̆. Ankara 2013.

Memik N. Ç., Yıldız Ö., Tural Ü. \& Ağaoğlu B. (2011). "Sosyal Fobinin Yaygınlığı: Bir Gözden Geçirme". Archives of Neuropsychiatry 48 (2011) 4-10.

Noyan H. \& Berk H. Ö. (2007). "Ergenlerde Sosyal Fobi, İçe ve Dışa Dönük Kişilik Özellikleri ve Okul Başarı Durumu. "XII. Ulusal Psikoloji Öğrencileri Kongresi. Yakın Doğu Üniversitesi, Kuzey Kıbrıs Türk Cumhuriyeti, Temmuz 2007.

Özbay Y. \& Palancı M. (2001). "Sosyal Kaygı Ölçeği: Geçerlik Güvenirlik Çalışması". VI. Ulusal Psikolojik Danışma ve Rehberlik Kongresi. Ortadoğu Teknik Üniversitesi, Ankara, Eylül 2001.

Palancı M. (2004). Üniversite Öğrencilerinin Sosyal Kaygı Problemlerini Açıklama ve Gidermeye Yönelik Gerçeklik Terapisi Oryantasyonlu Bir Yardım Modelinin Geliştirilmesi. Yayımlanmamış Doktora Tezi. Karadeniz Teknik Üniversitesi, Sosyal Bilimler Enstitüsü, Trabzon 2004.

Rapee R. M. (1995). Social Phobia. New York 1995.

Schneier F. R., Johnson J., Hornig C. D., Liebowitz M. R.V. \& Weissman M. M. (1992). "Social Phobia Comorbidity and Morbidity in an Epidemiologic Sample". Archives of General Psychiatry 49/4 (1992) 282-288.

Talepasand S. \& Nokani N. (2010). "Social Phobia Symptoms: Prevalence and Sociodemographic Correlates". Archives of Iranian Medicine 13/6 (2010) 522-527.

Thomasson P. \& Psouni E. (2010). "Social Anxiety and Related Social Impairment are Linked to SelfEfficacy and Dysfunctional Coping". Scandinavian Journal of Psychology 51 (2010) 171-178.

Tillfors M. \& Furmark T. (2007). "Social Phobia in Swedish University Students: Prevalence, Subgroups and Avoidant Behavior". Social Psychiatry and Psychiatric Epidemiology 42 (2007) 79-86.

Türe H. (2009). Celal Bayar Üniversitesi Tip Fakültesi Öğrencilerinde Sosyal Kaygı Düzeyini Etkileyen Faktörler. Uzmanlık Tezi. Celal Bayar Üniversitesi, Tıp Fakültesi, Manisa 2009.

Ümmet D. (2007). Üniversite Ögrrencilerinde Sosyal Kaygının Cinsiyet Rolleri ve Aile Ortamı Bağlamında Incelenmesi. Yayımlanmamış Yüksek Lisans Tezi. Marmara Üniversitesi, Eğitim Bilimleri Enstitüsü, İstanbul 2007.

Weinstock L. S. (1999). "Gender Differences in the Presentation and Management of Social Anxiety Disorder". The Journol of Clinical Psychiatry 60/9 (1999) 9-13.

Yeniçıktı N. T. (2010). Halkla İlişkiler Sürecinde Sosyal Kaygı Düzeylerinin Sosyal Sorumluluk Projeleri ile Giderilmesi. Yayımlanmamış Yüksek Lisans Tezi. Selçuk Üniversitesi, Sosyal Bilimler Enstitüsü, Konya 2010. 